NOTE

\title{
A Case of Gitelman's Syndrome with Chondrocalcinosis
}

\author{
NaOKo HISAKAWA, NobuKazU YASUOKA, Hiroyuki ITOH, TOSHIHIRo TAKAO, \\ CHISA JINNOUCHI, KoJI NISHIYA, AND KOZO HASHIMOTO
}

Second Department of Internal Medicine, Kochi Medical School, Kochi 783, Japan

\begin{abstract}
A 45-year-old Japanese woman, treated for Bartter's syndrome for 14 years, presented with complaints of numbness in her extremities and polyarthralgia. She was diagnosed to have Gitelman's syndrome with chondrocalcinosis, which were effectively treated with spironolactone and magnesium supplementation. Gitelman's syndrome is a primary renal tubular disorder characterized by hypomagnesemia and hypocalciuria with normal calcemia. The persistent hypomagnesemia is one of the causes of chondrocalcinosis, and many cases of Bartter's syndrome with hypomagnesemia are associated with chondrocalcinosis attributed to a tubular magnesium defect. We summarize the reported cases with Bartter's syndrome and chondrocalcinosis, referring to the possibility of Gitelman's syndrome.
\end{abstract}

Key words: Bartter's syndrome, Chondrocalcinosis, Gitelman's syndrome, Hypomagnesemia

(Endocrine Journal 45: 261-267, 1998)

BARTTER'S syndrome, first reported in 1962, is characterized by hypokalemia, metabolic alkalosis, hyperreninemia, hyperplasia of the juxtaglomerular cells and normal blood pressure [1]. Gitelman's syndrome was initially reported as a "familial disorder characterized by hypokalemia and hypomagnesemia" in 1966 [2]. These disorders had been often confused because of their similar clinical features, but urinary calcium levels have been clinically useful in separating patients with primary hypokalemic metabolic alkalosis into two groups, i.e. classic Bartter's syndrome and Gitelman's syndrome [3]. Recently the pathogenesis of Gitelman's syndrome has been reported to be mutations of the gene encoding thiazide-sensitive $\mathrm{Na}-\mathrm{Cl}$ cotransporter [4].

In addition, hypomagnesemia has been associated on several occasions with calcium pyrophosphate deposition disease (CPPDD,

Received: July 28, 1997

Accepted: December 9, 1997

Correspondence to: Dr. Naoko HISAKAWA, Second Department of Internal Medicine, Kochi Medical School, Kohasu, Okoh-cho, Nankoku , Kochi 783, Japan chondrocalcinosis). Since the first report in 1978 of the association between Bartter's syndrome and chondrocalcinosis, 25 cases have been published [5-19]. Because all the data in these reports showed hypomagnesemia and hypocalciuria, they might indicate Gitelman's syndrome, not Bartter's syndrome.

In this paper, we describe a patient with Gitelman's syndrome and chondrocalcinosis who has been successfully treated with spironolactone and magnesium supplementation.

\section{Case Report}

A 45-year-old Japanese woman was admitted to our hospital in December, 1994 for evaluation of numbness in her extremities and dyspnea. There was no family member with similar symptoms or renal disease, and her parents were nonconsanguineous. She grew up normally and had no childhood history of tetany. There also was no history of vomiting or gastrointestinal disease, or abuse of diuretics, laxatives or other medications. 
Hypokalemia had been first revealed in 1980 when she initially experienced dyspnea and numbness in her extremities. Because of hyperreninemia, hyperaldosteronism, the resistance to the pressor effects of angiotensin II, and hyperplasia of her juxtaglomerular cells, she had been diagnosed as having Bartter's syndrome in the former hospital. Since she came to our hospital with complaints of palpitation, numbness and dyspnea in 1982, she has been treated with spironolactone (25 mg/day) and potassium supplementation (32 mEq/day). Although her serum potassium concentration was slightly increased and maintained at $2.9-3.3 \mathrm{mEq} / l$ with medication, mild numbness and dyspnea continued with gradual progression. The dose of spironolactone could not be increased to more than $50 \mathrm{mg} /$ day, because prolongation of menstruation was found to be due to the drug. Meanwhile, hypomagnesemia was discovered in 1986.

Since 1990 she had been suffering from recurrent episodes of pain in her knees, shoulders and elbows; these attacks, lasting several days, were accompanied by a fever and improved by the administration of non steroidal anti inflammatory drugs. In 1992 chondrocalcinosis was found to be due to calcification in the joint spaces in her knees and symphysis pubis.

On physical examination, her height was 150.3 $\mathrm{cm}$ and weight $39.2 \mathrm{~kg}$. Her blood pressure was 92/60 mmHg. Trousseau's sign and Chvostek's sign were both absent.

Laboratory data on admission revealed total serum protein, $6.8 \mathrm{mg} / \mathrm{d} l$; serum albumin, $4.5 \mathrm{mg}$ / $\mathrm{d} l$; creatinine, $0.5 \mathrm{mg} / \mathrm{d} l$; blood urea nitrogen, 10 $\mathrm{mg} / \mathrm{d} l$; and uric acid, $4.1 \mathrm{mg} / \mathrm{d} l$. Serum values included the following: sodium, $137 \mathrm{mEq} / \mathrm{l}$; potassium, $2.8 \mathrm{mEq} / l$; chloride, $102 \mathrm{mEq} / l$; magnesium, $1.2 \mathrm{mEq} / l$ (normal $1.6-2.1 \mathrm{mEq} / \mathrm{l}$ ); calcium, $5.0 \mathrm{mEq} / l$; ionized calcium, $2.64 \mathrm{mEq} / l$ (normal 2.27-2.63 mEq/l); and phosphate, $1.4 \mathrm{mEq}$ / l. Urinary potassium was $55.8 \mathrm{mEq} /$ day; urinary chloride, $138.6 \mathrm{mEq} /$ day; urinary magnesium, 7.7 $\mathrm{mEq} /$ day; and urinary calcium, $0.54 \mathrm{mEq} /$ day. The endogenous creatinine clearance was $119.9 \mathrm{ml} / \mathrm{min}$. The molar urinary calcium/creatinine ratio was 0.04 . On hormonal examination, the plasma renin activity was $37.3 \mathrm{ng} / \mathrm{ml} / \mathrm{h}$; aldosterone, $45 \mathrm{ng} / \mathrm{dl}$; angiotensin I, $2760 \mathrm{pg} / \mathrm{ml}$ (normal $<500 \mathrm{pg} / \mathrm{d} l$ ); angiotensin II, $160 \mathrm{pg} / \mathrm{ml}$ (normal 9-47 pg/ml); and intact PTH, $27 \mathrm{pg} / \mathrm{ml}$. The intravenous infusion of $72 \mathrm{mEq}$ magnesium (3.6 g magnesium sulfate) caused the serum magnesium level to transiently increase to $2.2 \mathrm{mEq} / l$ before decreasing to $1.5 \mathrm{mEq} / l$ the next day. The urinary excretion of magnesium was $33 \mathrm{mEq} /$ day, suggesting that the renal magnesium wasting was responsible for the hypomagnesemia. Radiographs revealed chondrocalcinosis of the menisci in the knees (Fig. 1) and symphysis pubis (Fig. 2).

Treatment with increasing doses of spironolactone (50 mg/day) and oral magnesium (magnesium oxide $0.3 \mathrm{~g} /$ day) was started, along with continuation of the potassium supplementation. Although the serum potassium level increased to greater than $3 \mathrm{mEq} / l$, the serum magnesium level did not change. Weekly intravenous drip infusion of magnesium sulfate (32 $\mathrm{mEq}$ ) was therefore initiated. Despite persistent hypomagnesemia, the polyarthralgia improved and the high fever had been reduced (Fig. 3).

\section{Discussion}

Our patient manifested all of the characteristic findings of Bartter's syndrome, including the laboratory examination and renal histology done by biopsy. In addition, hypomagnesemia due to renal magnesium wasting and hypocalciuria were

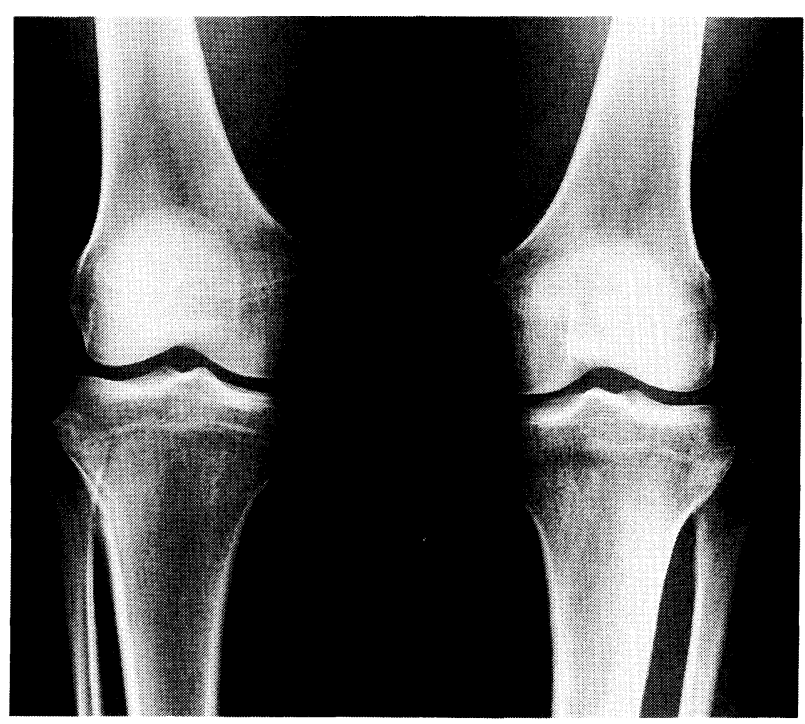

Fig. 1. Chondrocalcinosis of the menisci in the knee. 
present. These features are compatible with Gitelman's syndrome, that was first described by Gitelman in 1966 [2]. Patients with Gitelman's syndrome tend to have a milder and later developing course, manifesting renal magnesium wasting and hypocalciuria [3].

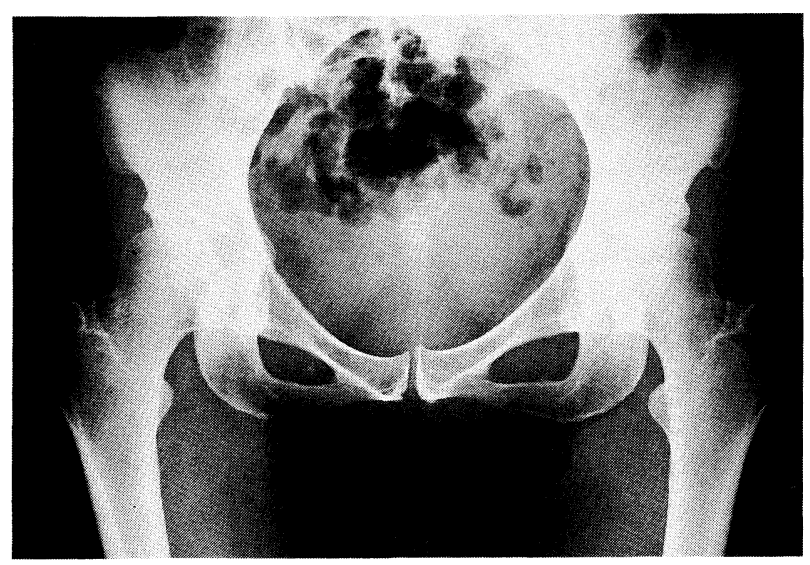

Fig. 2. Chondrocalcinosis of the symphysis pubis.
Renal magnesium wasting is defined as the urinary excretion of more than $1 \mathrm{mmol} /$ day of magnesium in the presence of hypomagnesemia (plasma magnesium $<0.7 \mathrm{mmol} / l$ ) [20]. Sixty-five percent of magnesium reabsorption takes place in the ascending loop of Henle, driven by the electrical gradient generated by the active reabsorption of chloride. Hypomagnesemia with renal magnesium wasting is demonstrated not only in all patients with Gitelman's syndrome, but also in $20-39 \%$ of those with Bartter's syndrome which might have involved Gitelman's syndrome in previous reports $[20,21]$.

Nevertheless, these two syndromes may be differentiated by the laboratory examination of the calcium excretion. The patients whose calcium excretion is consistently reduced (molar urinary calcium/creatinine ratio $<0.10$ ) are diagnosed as having Gitelman's syndrome, while the patients whose calcium excretion is normal or increased (molar urinary calcium/creatinine ratio $>0.20$ ) are diagnosed as having Bartter's syndrome [3]. The differences in calcium excretion may result from

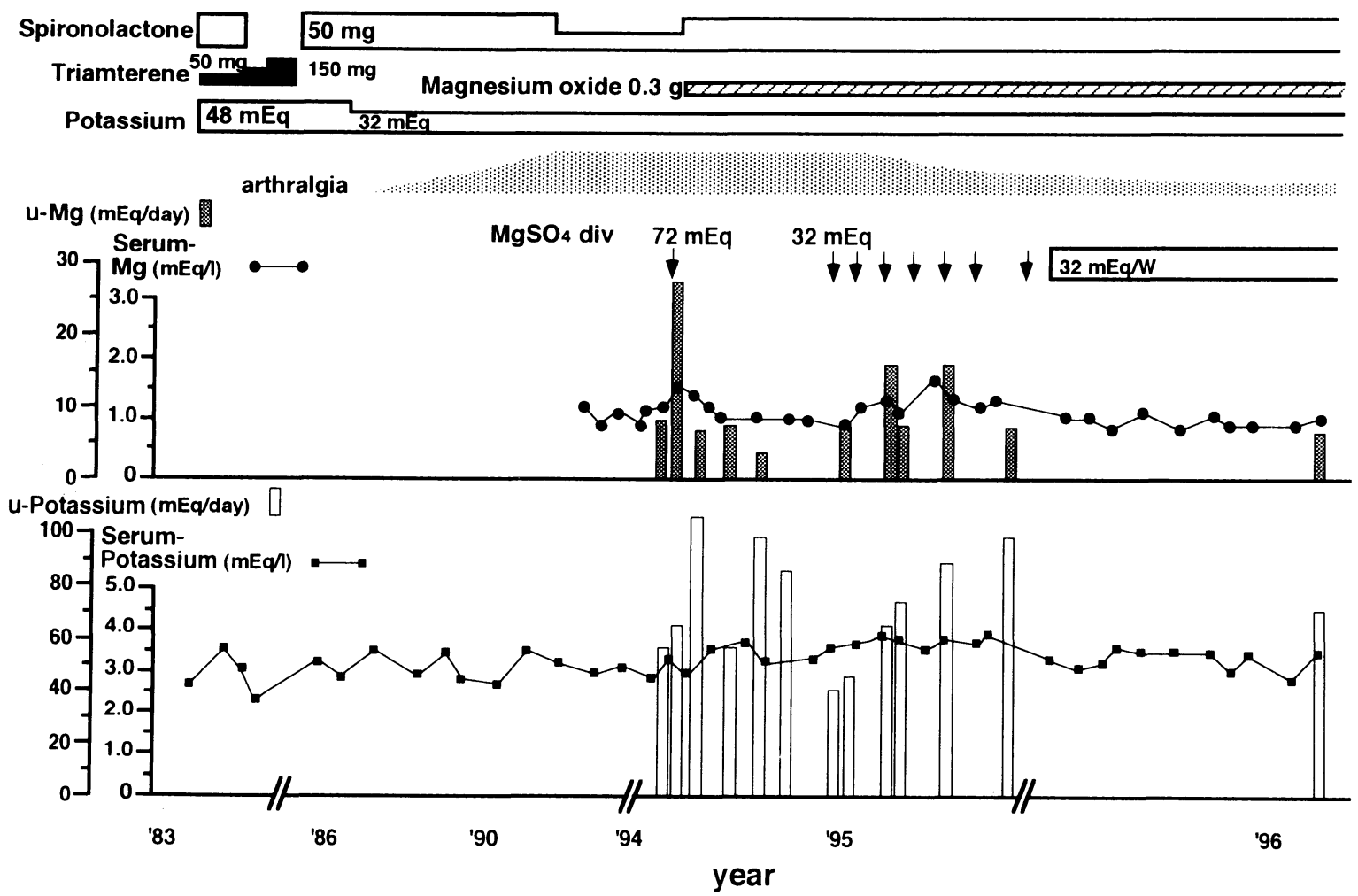

Fig. 3. The clinical course of our patient, a 45-year-old Japanese woman with Gitelman's syndrome and chondrocalcinosis. 
different sites of tubular involvement. As calcium and magnesium are absorbed in parallel in Henle's loop, Bartter's syndrome, with its defect at this site, manifests as hypercalciuria and magnesium wasting. As calcium and magnesium transport can be dissociated in the distal convoluted tubule, which is the site of the defect in Gitelman's syndrome [3, 22-24], these patients manifest magnesium wasting and hypocalciuria. Simon et al. demonstrated a wide variety of non-conservative mutations in the gene encoding renal thiazidesensitive $\mathrm{Na}-\mathrm{Cl}$ cotransporter (TSC) in the patients with Gitelman's syndrome and proposed that the mutant alleles result in a defect in normal TSC function [4], although our patient wasn't been performed gene analysis. The mechanism of the defect causing hypomagnesemia and hypocalciuria is unclear, but the physiological features of Gitelman's syndrome appear to be derived from a mutation in TSC, because these same effects are seen in patients taking thiazide diuretics, specific inhibitors of TSC [4].

There are reports indicating that concentrations of ionized calcium are normal [25] or low [26] with a normal level of PTH and an association between hypocalciuria and a reduction in fractional excretion of ionized calcium in patients with Gitelman's syndrome. Colussi et al. suggested the possibility of an abnormal ionized calcium-PTH relationship related to hypomagnesemia [25].

Our patient had polyarthralgia due to chondrocalcinosis for ten years after revealing hypokalemia. Twenty-five cases of Bartter's syndrome with chondrocalcinosis including familial presentation have been reported since 1978 [5], and hypomagnesemia was always presented in these cases (Table 1). The mean age at revealing hypokalemia in these cases was 42.8 years old, which is a late presentation for Bartter's syndrome. The fact that all the patients (except one), with urinary calcium had hypocalciuria, also indicated that these cases had a high possibility of Gitelman's syndrome not Bartter's syndrome.

Chondrocalcinosis is caused by the release of lysosomal enzymes from polymorphonuclear leukocytes in response to phagocytosis of calciumpyrophosphate-dihydrate (CPPD) crystals. Hypomagnesemia is considered to be one of the causes of chondrocalcinosis. There is in vitro evidence suggesting a relationship between hypomagnesemia and chondrocalcinosis; 1) magnesium is a cofactor for pyrophosphatase and magnesium depletion decreases the activity of pyrophosphatase, increasing the level of pyrophosphate [27], 2) magnesium ions increase the solubility of CPPD crystals [28]. It is not clear whether the tendency to hypercalcemia in the patients with Gitelman's syndrome contributes to the deposition of CPPD crystals. Since our patient had no factor of chondrocalcinosis except hypomagnesemia, persistent hypomagnesemia for over 4 years is considered to be the cause of chondrocalcinosis.

Magnesium supplementation is considered to be effective in inhibiting progression of chondrocalcinosis. Salvarani et al. described a patient who showed no progression of chondrocalcinosis (no radiological increase in the calcified deposits and absence of acute attacks of arthritis) after treatment with magnesium supplementation and indomethacin [12]. Smilde et al. described familial cases with the longest follow up (about 10 years). The patients kept on magnesium supplementation had remained free of clinical symptoms and regression or no radiological increase in calcified deposits. In contrast, progression had been observed in other patients who refused or stopped magnesium supplementation [18]. On the other hand, antialdosterone therapy is effective in ameliorating hypokalemia and hypomagnesemia in Gitelman's syndrome. Its effects appear to result mainly from a direct tubular effect on potassium secretion and magnesium reabsorption [23]. In our patient, after starting treatment with magnesium supplementaion (oral magnesium oxide and intravenous magnesium sulfate) besides antialdosterone therapy, the severity of acute attacks became milder and the calcification did not increase, although serum magnesium did not reach completely normal levels.

The long-term clinical course and growth of patients with Gitelman's syndrome is considered to be good [29], but we should note that Gitelman's syndrome may be accompanied with a complication due to persistent hypomagnesemia, such as chondrocalcinosis. Long-term hypomagnesemia causes chondrocalcinosis, and antialdosterone therapy and magnesium supplementation is important in protecting against complications. 
Table 1. Previously reported cases of Bartter's syndrome with chondrocalcinosis

\begin{tabular}{|c|c|c|c|c|c|c|}
\hline Source & Sex & $\begin{array}{l}\text { Age of onset } \\
\text { of arthritis } \\
\text { (years) }\end{array}$ & $\begin{array}{c}\text { Age of revealing } \\
\text { hypokalemia } \\
\text { (years) }\end{array}$ & $\begin{array}{l}\text { Plasma Mg } \\
\text { (normal value) }\end{array}$ & $\begin{array}{c}\text { urinary } \\
\mathrm{Ca}\end{array}$ & $\begin{array}{l}\text { urinary } \\
\text { Ca/Crn }\end{array}$ \\
\hline $\begin{array}{l}\text { Schwartz et al. } \\
1978 \text { [5] }\end{array}$ & M & 32 & 52 & $\begin{array}{l}0.29 \mathrm{mEq} / l \\
(0.46-0.89)\end{array}$ & - & \\
\hline $\begin{array}{l}\text { Bauer et al. } \\
1979[6]\end{array}$ & $\begin{array}{l}\mathrm{M} \\
\mathrm{F}\end{array}$ & 24 & $\begin{array}{l}36 \\
40\end{array}$ & $\begin{array}{l}0.4 \mathrm{mmol} / l \\
0.53 \mathrm{mmol} / l \\
(0.75-1.25)\end{array}$ & - & \\
\hline $\begin{array}{l}\text { Goulon et al. } \\
1980 \text { [7] }\end{array}$ & $\begin{array}{l}\mathrm{F} \\
\mathrm{M}\end{array}$ & $\begin{array}{l}37 \\
27\end{array}$ & $\begin{array}{l}32 \\
42\end{array}$ & $\begin{array}{r}16 \mathrm{mg} / \mathrm{l} \\
14 \mathrm{mg} / \mathrm{l} \\
(21 \pm 4)\end{array}$ & - & \\
\hline $\begin{array}{l}\text { Hurault et al. } \\
1981[8]\end{array}$ & $\mathrm{F}$ & 24 & 21 & $\begin{array}{l}0.48 \mathrm{mmol} / \mathrm{l} \\
(0.78-0.98)\end{array}$ & - & \\
\hline $\begin{array}{l}\text { de Bruyne et al. } \\
1982 \text { [9] }\end{array}$ & $\mathrm{M}$ & 32 & 36 & $\begin{array}{l}0.7 \mathrm{mEq} / l \\
(1.5-2.5)\end{array}$ & - & \\
\hline $\begin{array}{l}\text { Mayoux-Beuhamou } \\
\text { et al. } 1985 \text { [10] }\end{array}$ & $\begin{array}{l}F \\
F\end{array}$ & $\begin{array}{l}26 \\
56\end{array}$ & $\begin{array}{l}31 \\
44\end{array}$ & $\begin{array}{l}0.55 \mathrm{mmol} / l \\
0.35 \mathrm{mmol} / l \\
(0.74-0.90)\end{array}$ & & $\begin{array}{c}0.015 \\
0.10 \\
(0.1-0.3)\end{array}$ \\
\hline $\begin{array}{l}\text { Dupond et al. } \\
1989 \text { [11] }\end{array}$ & F & & & $\begin{array}{l}0.48 \mathrm{mmol} / \mathrm{l} \\
(0.75-0.90)\end{array}$ & & $\begin{array}{c}0.04 \\
(0.1-0.3)\end{array}$ \\
\hline $\begin{array}{l}\text { Salvarani et al. } \\
1989 \text { [12] }\end{array}$ & M & 31 & 31 & $\begin{array}{l}0.8 \mathrm{mg} / \mathrm{d} l \\
(1.6-2.5)\end{array}$ & & - \\
\hline $\begin{array}{l}\text { Pagès et al. } \\
1991 \text { [13] }\end{array}$ & & & & $\begin{array}{l}0.45 \mathrm{mmol} / l \\
0.43 \mathrm{mmol} / l \\
(0.7-1.0)\end{array}$ & $\begin{array}{l}49 \mathrm{mg} / \mathrm{g} . \mathrm{crn} \\
22.5 \mathrm{mg} / \mathrm{g} . \mathrm{crn} \\
(70-190)\end{array}$ & \\
\hline $\begin{array}{l}\text { de Heide et al. } \\
1991 \text { [14] } \\
\text { de Fillipi et al. } \\
1992 \text { [15] }\end{array}$ & $\mathrm{F}$ & 44 & 24 & $\begin{array}{l}0.65 \mathrm{mmol} / l \\
(0.85-1.0) \\
0.52 \mathrm{mmol} / l \\
(0.70-0.90)\end{array}$ & $\begin{array}{l}- \\
-\end{array}$ & \\
\hline $\begin{array}{l}\text { Jones et al. } \\
1992 \text { [16] }\end{array}$ & $\mathrm{F}$ & 49 & 50 & $\begin{array}{l}0.5 \mathrm{mmol} / l \\
(0.7-1.0)\end{array}$ & - & \\
\hline $\begin{array}{l}\text { Waitman et al. } \\
1992 \text { [17] }\end{array}$ & M & & 60 & $\begin{array}{l}0.75 \mathrm{mg} / \mathrm{d} l \\
(1.7-2.4)\end{array}$ & - & \\
\hline $\begin{array}{l}\text { Smilde et al. } \\
1994 \text { [18] }\end{array}$ & $\begin{array}{c}\mathrm{F} \\
\mathrm{M} \\
\mathrm{M} \\
\mathrm{F} \\
\mathrm{M} \\
\mathrm{M} \\
\mathrm{M}\end{array}$ & 39 & $\begin{array}{l}54 \\
56 \\
59 \\
41 \\
37 \\
43 \\
44\end{array}$ & $\begin{array}{l}0.56 \mathrm{mmol} / l \\
0.60 \mathrm{mmol} / l \\
0.60 \mathrm{mmol} / l \\
0.49 \mathrm{mmol} / l \\
0.54 \mathrm{mmol} / l \\
0.49 \mathrm{mmol} / l \\
0.52 \mathrm{mmol} / l \\
(0.80-1.20)\end{array}$ & $\begin{array}{c}2.80 \mathrm{mmol} / \text { day } \\
2.20 \mathrm{mmol} / \text { day } \\
1.10 \mathrm{mmol} / \text { day } \\
1.16 \mathrm{mmol} / \text { day } \\
1.95 \mathrm{mmol} / \text { day } \\
1.95 \mathrm{mmol} / \text { day } \\
1.82 \mathrm{mmol} / \text { day } \\
\quad(2.5-7.5)\end{array}$ & \\
\hline $\begin{array}{l}\text { Muñoz-Fernández } \\
\text { et al. 1994 [19] }\end{array}$ & M & 65 & 65 & $\begin{array}{l}1.2 \\
(1.4-2.1)\end{array}$ & - & \\
\hline
\end{tabular}

Ca, Calcium; Crn, creatinine; $\mathrm{Mg}$, magnesium; $\mathrm{M}$, male; F, female. 


\section{References}

1. Bartter FC, Pronove P, Gill JR, MacCardle RC (1962) Hyperplasia of the juxtaglomerular complex with hyperaldosteronism and hypokalemic alkalosis. $\mathrm{Am}$ J Med 33: 811-828.

2. Gitelman HJ, Graham JB, Welt LG (1966) A new familial disorder characterized by hypokalemia and hypomagnesemia. Trans Assoc Am Physicians 79: 221-235.

3. Bettinelli A, Bianchetti MG, Girardin E, Caringella A, Cecconi M, Appiani AC, Pavanello L, Gastaldi R, Isimbaldi C, Lama G, Marchesoni C, Matteucci C, Patriarca P, Natale BD, Setzu C, Vitucci P (1992) Use of calcium excretion values to distinguish two forms of primary renal tubular hypokalemic alkalosis: Bartter and Gitelman syndromes. J Pediatr 120: 38-43.

4. Simon DB, Nelson-Williams C, Bia MJ, Ellison D, Karet FE, Molina AM, Vaara I, Iwata F, Cushner HM, Koolen M, Gainza FJ, Gitelman HJ, Lifton RP (1996) Gitelman's variant of Bartter's syndrome, inherited hypokalaemic alkalosis, is caused by mutations in the thiazide-sensitive $\mathrm{Na}-\mathrm{Cl}$ cotransporter. Nature Genet 12: 24-30.

5. Schwarz HA, Weidmann P, Masserli FH, Zia PK, Flammer J, Reubi FC (1978) Increased levels of renal venous and peripheral prostaglandin E-like activity in Bartter's syndrome. Miner Electrolyte Metab 1: 288294.

6. Bauer FM, Glasson Ph, Vallotton MB, Courvoisier B (1979) Syndrome de Bartter, chondrocalcinose et hypomagnésémie. Schweiz medd Wschr 109: 12511256 (In French).

7. Goulon M, Raphael JC, De Rohan P (1980) Syndrome de Bartter et chondrocalcinose. Nouv Press Med 9: 1291-1295 (Abstract in English).

8. Hurault de Ligny B, Baumelou A, Bardin T, Buyse N, Mehaut M (1981) Chondrocalcinose au cours du syndrome de Bartter. Nouv Press Med 10: 107 (In French).

9. de Bruyne J, Chappel R, Mortier G, Debroe M, Holvoet J (1982) Bartter's syndrome and chondrocalcinosis. J Belge Med Phys Rehabil 5: 37-45 (Abstract in English).

10. Mayoux-Beuhamou MA, Clerc D, Ganeval D, Pertuisset N, Massias P (1985) Chondrocalcinose articulaire et hypomagnésémie d'origine rénale. Rev Rheum 52: 545-548 (Abstract in English).

11. Dupond JL, Humbert $P$, de Wazières $B$, Wolf JP (1989) Syndrome de Bartter, chondrocalcinose articulaire diffuse et hypomagnésémie néphrogénique chez un adulte. Rev Med Interne 10: 261-264 (Abstract in English).

12. Salvarani C, Rossi F, Macchioni PL, Baricchi R,
Capozzoli N, Castellani S, Ghirelli L, Veneziani M, Scarti L, Portioli I (1989) Bartter's syndrome and chondrocalcinosis: A possible role for hypomagnesemia in the deposition of calcium pyrophosphate dihydrate (CPPD) crystals. Clin Exp Rheumatol 7: 415-420.

13. Pagès $M$, Amigues JM, Dromer $C$, Billey $T$, Fournié B, Fournié A (1991) Chondrocalcinose articulaire diffuse révélant un syndrome de Bartter. Rev Rheum Mal Osteoartic 58: 619-621 (In French).

14. de Heide LJM, Birkenhäger JC (1991) Bartter's syndrome, hypomagnesaemia and chondrocalcinosis. Neth J Med 39: 148-152.

15. de Fillipi JP, Diderich PhPNM, Wouters JMGW (1992) Hypomagnesiëmie en chondrocalcinosis. Ned Tijdschr Geneesk 136: 139 (In Dutch).

16. Jones AC, Chuck AJ, Arie EA, Green DJ, Doherty M (1992) Diseases associated with calcium pyrophosphate deposition disease. Semin Arthritis Rheum 22: 188-202.

17. Waitman AD, Koffler M, Kaplinsky N (1992) Bartter's syndrome presenting as pseudomyocardial infarction and pseudogout. Isr J Med Sci 28: 885887.

18. Smilde TJ, Haverman JF, Schipper P, Hermus ARMM, Liebergen FJHM, Jansen JLJ, Kloppenborg PWC, Koolen MI (1994) Familial hypokalemia/ hypomagnesemia and chondrocalcinosis. J Rheumatol 21: 1515-1519.

19. Muñoz-Fernández S, Pantoja L, Mola EM, de Miguel E, Baños JG (1994) Chondrocalcinosis associated with Bartter's syndrome and hypomagnesemia. J Rheumatol 21: 1782-1783.

20. Sutton RAL, Domrongkitchaiporn S (1993) Abnormal renal magnesium handling. Miner Electrolyte Metab 19: 232-240.

21. Stein JH (1985) The pathogenetic spectrum of Bartter's syndrome. Kidney Int 28: 85-93.

22. Sutton R, Mavichak V, Halabe A, Wilkins G (1992) Bartter's syndrome: Evidence suggesting a distal tubular defect in a hypocalciuria variant of the syndrome. Miner Electrolyte Metab 18: 43-51.

23. Colussi G, Rombolà G, De Ferrari M, Macaluso M, Minetti L (1994) Correction of hypokalemia with antialdosterone therapy in Gitelman's syndrome. Am J Nephrol 14: 127-135.

24. Tsukamoto T, Kobayashi T, Kawamoto K, Fukase M, Chihara K (1995) Possible discrimination of Gitelman's syndrome from Bartter's syndrome by renal clearance study: Report of two cases. $A m J$ Kidney Dis 25: 637-641.

25. Collusi G, Macaluso M, Brunati C, Minetti L (1994) Calcium metabolism and calciotropic hormone 
levels in Gitelman's syndrome. Miner Electrolyte Metab 20: 294-301.

26. Bianchetti MG, Bettinelli A, Casez JP, Baslico E, Metta MG, Spicher I, Santeramo C, Bigoni M, Jaeger PH (1995) Evidence for disturbed regulation of caciotropic hormone metabolism in Gitelman's syndrome. J Clin Endocrinol Metab 80: 224-228.

27. McCarty DJ, Solomon SD, Warnock ML, Paloyan E (1971) Inorganic pyrophosphate concentrations in the synovial fluid of arthritic patients. J Lab Clin Med 78: 216-229.

28. Bennett RM, Lehr JR, McCarty DJ (1975) Factors affecting the solubility of calcium pyrophosphate dihydrate crystals. J Clin Invest 56: 1571-1579.

29. Bettinelli A, Metta MG, Perini A, Basilico E, Santeramo C (1993) Long-term follow-up of a patient with Gitelman's syndrome. Pediatr Nephrol 7: 67-68. 